\title{
5-HT1B Receptors: A Novel Target for Lithium Possible Involvement in Mood Disorders
}

\author{
Olivier Massot, Ph.D., Jean-Claude Rousselle, Ph.D., Marie-Paule Fillion, M.Sc., \\ Dominique Januel, M.D., Mathieu Plantefol, M.Sc., and Gilles Fillion, Ph.D.
}

\begin{abstract}
Lithium ion is widely used to treat depressive patients, often as an initial helper for antidepressant drugs or as a mood stabilizer; however, the toxicity of the drug raises serious problems, because the toxic doses of lithium are quite close to the therapeutic ones. Thus, precise characterization of the target(s) involved in the therapeutic activity of lithium is of importance. The present work, carried out at molecular, cellular, and in vivo levels, demonstrates that $5-\mathrm{HT}_{1 B}$ receptor constitutes a molecular target for lithium. Several reasons suggest that this interaction is more likely related to the therapeutic properties of lithium than to its undesirable effects. First, the observed biochemical and functional
\end{abstract}

interaction occurs at concentrations that precisely correspond to effective therapeutic doses of lithium. Second, $5-\mathrm{HT}_{1 B}$ receptors are well characterized as controlling the activity of the serotonergic system, which is known to be involved in affective disorders and the mechanism of action of various antidepressants. These findings represent progress in our knowledge of the mechanism of action of lithium that may facilitate clinical use of the ion and also open new directions in the research of antidepressant therapies. [Neuropsychopharmacology 21:530-541, 1999] (C) 1999 American College of

Neuropschopharmacology. Published by Elsevier Science Inc.
KEY WORDS: Lithium; Mood disorders; Serotonin receptors; Pharmacology; Drug interactions; Antidepressant therapy

Lithium is a simple monovalent cation that represents one of the most important compounds used in psychiatry. It is widely used and remains the most effective treatment for mania and for the prevention of recurrent episodes in both mania and depression (Schildkraut 1973; Schou and Thomsen 1975; Wood and Goodwin 1987; Price et al. 1990; Odagaki et al. 1992; Price and Heninger 1994; Schou 1997; Gershon and Soares 1997; Soares and Gershon 1998).

Despite extensive research, the molecular mecha-

From the Unité de Pharmacologie Neuro-Immuno-Endocrinienne, Institut Pasteur, Paris, France.

Address correspondence to: Dr. G. Fillion, Institut Pasteur, Unite de Pharmacologie Neuro-Immuno-Endocrinienne, 25-28 rue du Dr Roux, 75724 Paris, Cedex 15, France.

16 November 1998; revised 12 March 1999; accepted 22 March 1999 nism underlying its therapeutic action has not been fully elucidated, and no precise site of action has been identified yet, at least for therapeutic concentrations attained in the brain of patient. Nevertheless, a wide variety of biochemical effects have been reported, of which the most documented is the interaction of lithium with signal transduction pathways coupled to membrane receptors. Indeed, lithium has been shown to interact both with the phosphatidyl inositol turnover reducing brain inositol levels and with the adenylate cyclase activities, reducing receptor stimulated adenylate cyclase activity. These interactions of lithium are likely involved in the general profile of clinical activities of the ion (Wood and Goodwin 1987; Price and Heninger 1994; Manji et al. 1995; Belmaker et al. 1996; Attack 1996).

Focusing on the serotonergic system, whose activity is considered to be reduced in depression (Price et al. 1990; Odagaki et al. 1992; Siever et al. 1991; GrahameSmith 1992), numerous reports have shown, in vitro as 
well as in vivo, that lithium has the capacity to induce an increase in the release of serotonin (5-hydroxytryptamine, 5-HT) at the synaptic level (Green and Grahame-Smith 1976; Treiser et al. 1981; Blier and de Montigny 1985; Hotta et al. 1986; Wood and Goodwin 1987; Blier et al. 1987; Friedman and Wang 1988; Wang and Friedman 1988; Hotta and Yamawaki 1988; Hide and Yamawaki 1989; Sharp et al. 1991; Price and Heninger 1994) and can also potentiate antidepressant treatments (de Montigny et al. 1983; Cowen et al. 1991; Baumann et al. 1996). The biochemical mechanism responsible for these properties is not yet understood, although it has been suggested that 5-HT autoreceptors, and particularly $5-\mathrm{HT}_{1 \mathrm{~B}}$, could be responsible for these effects (Blier and de Montigny 1985; Hotta et al. 1986; Friedman and Wang 1988; Wang and Friedman 1988; Hotta and Yamawaki 1988; Hide and Yamawaki 1989).

However, neuronal 5-HT release can be modulated by different ways. A major one is interaction with its inactivating process, particularly the synaptosomal reuptake system, which is the target for classical antidepressant drugs as specific serotonin reuptake inhibitors (SSRIs) (Hyttel 1982; Owen et al. 1997), and other ways consist in altering the activity of presynaptic 5-HT autoreceptors; that is, $5-\mathrm{HT}_{1 \mathrm{~A}}$ and $5-\mathrm{HT}_{1 \mathrm{~B}}$ receptor subtypes. $5-\mathrm{HT}_{1 \mathrm{~A}}$ autoreceptors are localized on the soma and dendrites of the 5-HT neurons and control their firing; whereas, $5-\mathrm{HT}_{1 \mathrm{~B}}$ autoreceptors are localized on neuron terminals, where they are especially dedicated to the auto control of the release of 5-HT (Hoyer et al. 1994). With regard to the serotonin transporter or the 5$\mathrm{HT}_{1 \mathrm{~A}}$ receptor, results are rather controversial, because some studies have shown an interaction of lithium at these levels and others did not; whereas, few biochemical data were reported for $5-\mathrm{HT}_{1 \mathrm{~B}}$ receptor (Schildkraut 1973; Schou and Thomsen 1975; Treiser and Kellar 1980; Treiser et al. 1981; Wood and Goodwin 1987; Blier et al. 1987; Price et al. 1990; Odagaki et al. 1991; Odagaki et al. 1992; Plenge et al. 1992; Price and Heninger 1994; Okamoto et al. 1996; Schou 1997; Carli et al. 1997; Gershon and Soares 1997; Soares and Gershon 1998; Redrobe and Bourin 1999). The aim of this study was to determine whether or not lithium could interact with the $5-\mathrm{HT}$ system via this particular molecular target $\left(5-\mathrm{HT}_{1 \mathrm{~B}}\right)$, as was previously proposed (Blier and de Montigny 1985; Hotta et al. 1986; Friedman and Wang 1988; Wang and Friedman 1988; Hotta and Yamawaki 1988; Hide and Yamawaki 1989; Redrobe and Bourin 1999). The potential alteration of $5-\mathrm{HT}_{1 \mathrm{~B}}$ terminal autoreceptor by lithium could induce an increase of the availability of 5-HT in the synaptic cleft presumably leading, as in the case of SSRI, to an antidepressant-like effect. Thus, $5-\mathrm{HT}_{1 \mathrm{~B}}$ could represent a primary target for lithium that could result in the necessary biochemical changes for lithium's therapeutic activity in the treatment of mood disorders.

\section{MATERIALS AND METHODS}

\section{Materials}

$\left[{ }^{3} \mathrm{H}\right] 5-\mathrm{HT} \quad(3.66 \mathrm{TBq} / \mathrm{mmol}),\left[{ }^{125} \mathrm{I}\right]-\mathrm{Cyanopindolol}$ (74 $\mathrm{TBq} / \mathrm{mmol})$, and $\left[{ }^{3} \mathrm{H}\right] \mathrm{L} 694,247$ (851 $\left.\mathrm{GBq} / \mathrm{mmol}\right)$, $\left[{ }^{3} \mathrm{H}\right]$ Quinuclidinyl benzylate (QNB) $(1.74 \mathrm{TBq} / \mathrm{mmol})$ and $\left[{ }^{3} \mathrm{H}\right]$ Dihydroalprenolol (DHA) $(3.33 \mathrm{TBq} / \mathrm{mmol})$ were purchased from Amersham International (Buckinghamshire, UK). [ $\left.{ }^{3} \mathrm{H}\right] 8$-hydroxy-2[di-n-propylamino]tetralin (8-OH-DPAT) $\left.(5.71 \mathrm{TBq} / \mathrm{mmol}),{ }^{35} \mathrm{~S}\right] \mathrm{GTP} \gamma \mathrm{S}$ (74 $\mathrm{TBq} / \mathrm{mmol}),\left[{ }^{3} \mathrm{H}\right]$ Naloxone $(2.2 \mathrm{TBq} / \mathrm{mmol}),\left[{ }^{3} \mathrm{H}\right] \mathrm{cAMP}$ $(1.1 \mathrm{TBq} / \mathrm{mmol})$ and $\left[\alpha^{32} \mathrm{P}\right]$ ATP $(1,1 \mathrm{TBq} / \mathrm{mmol})$ were from Dupont NEN (USA). $\mathrm{LiCl}$ and other salts were obtained from Sigma-Aldrich. Mice (male Swiss $\mathrm{OF}_{1}, 3-4$ weeks old) and rats (adult male Wistar; 20-250 g) were obtained from Iffa Credo (L'Arbresle, France). Adult guinea pigs were purchassed from Elevage Lebeaux (Gambais, France). NIH 3T3 cells transfected with the r5- $\mathrm{HT}_{1 \mathrm{~B}}$ receptor gene and transfected $\mathrm{CHO}$ cells expressing the $\mathrm{h} 5-\mathrm{HT}_{1 \mathrm{~B}}$ receptor were kindly given by René Hen. Transfected $\mathrm{CHO}$ cells expressing $5-\mathrm{HT}_{6}$ receptor were given by Jean-Charles Schwartz.

\section{Membrane Preparation}

Receptor Bindings. Rat and guinea pig brain cortices were dissected on ice and homogenized for 30 seconds with an Ultra-Turrax apparatus in 5 volumes $(\mathrm{v} / \mathrm{w})$ of a $50 \mathrm{mM}$ Tris- $\mathrm{HCl}$ buffer $\mathrm{pH} 7.4$ containing $2 \mathrm{mM}$ ethylenediaminetetra-acetic acid (EDTA), $0.1 \mathrm{mM}$ phenyl methyl sulfonyl fluoride, and 5 IU/L aprotinin. The homogenate was then diluted in 30 volumes $(\mathrm{v} / \mathrm{w})$ of the same medium, incubated for 10 minutes at $37^{\circ} \mathrm{C}$ to remove endogenous ligands, and centrifuged $(17,500 \times g$ at $4^{\circ} \mathrm{C}$ for $5 \mathrm{~min}$ ). The resulting pellet was resuspended in 5 volumes of the same buffer, incubated for $10 \mathrm{~min}$ utes at $37^{\circ} \mathrm{C}$, and centrifuged as described above. The homogenate was washed two additional times, and the pellet was resuspended in the appropriate incubation buffer.

NIH $3 \mathrm{~T} 3$ or CHO cells $\left(10^{6} /\right.$ dish) were cultured for 48 hours in a Dulbecco's modified Eagle's medium supplemented with $10 \%$ calf serum, $0.3 \mathrm{mg} / \mathrm{ml}$ geniticin, 10 $\mathrm{IU} / \mathrm{L}$ penicillin, and $10 \mu \mathrm{g} / \mathrm{ml}$ streptomycin. Cells were then collected and extensively washed in a $50 \mathrm{mM}$ Tris$\mathrm{HCl}$ buffer, $\mathrm{pH} 7.4$, before homogenization. Membranes were then prepared as described above.

Uptake and Release. Rat brain synaptosomes (total brain minus cerebellum) were prepared according to the method of Cotman and Matthews (1971).

Human Blood Platelets. Blood samples, collected in tubes containing a $3.8 \%$ sodium citrate solution, were centrifuged $\left(180 \times \mathrm{g} / 10 \mathrm{~min} / 4^{\circ} \mathrm{C}\right)$. The supernatant was kept at $4^{\circ} \mathrm{C}$, and the pellet was centrifuged once again $\left(180 \times g / 10 \mathrm{~min} / 4^{\circ} \mathrm{C}\right)$. The two supernatants 
were pooled and centrifuged $\left(1,500 \times g / 10 \mathrm{~min} / 4^{\circ} \mathrm{C}\right)$. The supernatant was centrifuged once again $(3500 \times g /$ $20 \mathrm{~min} / 4^{\circ} \mathrm{C}$ ). The pellet was resuspended in a $50 \mathrm{~mm}$ Tris- $\mathrm{HCl}$ buffer $\mathrm{pH} 7.4$ at $25^{\circ} \mathrm{C}$ containing $2 \mathrm{mM}$ dithiothreitol and $1 \mathrm{mM}$ EDTA, homogenized for $5 \mathrm{~s}$ with a polytron and centrifuged $\left(18,000 \times \mathrm{g} / 20 \mathrm{~min} / 4^{\circ} \mathrm{C}\right)$.

$\left[{ }^{5} \mathrm{~S}\right]$ GTP $\gamma \mathrm{S}$ Binding. $\mathrm{CHO}$ cells stably expressing h5$\mathrm{HT}_{1 \mathrm{~B}}$ receptor protein were harvested in a cold phosphate buffer $\mathrm{pH} 7.4$ containing $0.1 \mathrm{mM}$ EDTA and centrifuged $\left(20 \mathrm{~min} / 48,000 \times g / 4^{\circ} \mathrm{C}\right)$. The pellet was then homogenized with a polytron in a $20 \mathrm{~mm}$ Hepes buffer $\mathrm{pH} 7.4$ containing $10 \mathrm{mM}$ EDTA and centrifuged $\left(48,000 \times \mathrm{g} / 4^{\circ} \mathrm{C} / 10 \mathrm{~min}\right)$. The resulting pellet was washed twice in a $20 \mathrm{mM}$ Hepes buffer $\mathrm{pH} 7.4$ containing $0.1 \mathrm{mM}$ EDTA, homogenized, and centrifuged $\left(48,000 \times g / 10 \mathrm{~min} / 4^{\circ} \mathrm{C}\right)($ Thomas et al. 1995). The pellet was then stored at $-80^{\circ} \mathrm{C}$ in fractions of 0.8 to $1 \mathrm{mg}$ protein $/ \mathrm{ml}$ until use.

Adenylate Cyclase Experiments. $\mathrm{h} 5-\mathrm{HT}_{1 \mathrm{~B}} \mathrm{CHO}$ transfected cells were collected, extensively washed in a 50 $\mathrm{mM}$ Tris- $\mathrm{HCl}$ buffer $\mathrm{pH} 7.4$, and centrifugated.

Protein Measurement. Protein equivalents were determined according to the method of Lowry et al. (1951). Bovine serum albumin was used as standard.

\section{Dose-Response Curve on 5- $\mathrm{HT}_{1 \mathrm{~B}}$ Receptors}

Binding of $\left[{ }^{3} \mathrm{H}\right] 5-\mathrm{HT}(30 \mathrm{nM})$ to $5-\mathrm{HT}_{1 \mathrm{~B}}$ receptors were performed on membranes from rat brain or from transfected cells (NIH 3T3 expressing the $\mathrm{r} 5-\mathrm{HT}_{1 \mathrm{~B}}$ and $\mathrm{CHO}$ transfected with the gene coding for the $\left.\mathrm{h} 5-\mathrm{HT}_{1 \mathrm{~B}}\right)$. Membranes $(250 \mu \mathrm{g}$ in a final volume of $1 \mathrm{ml})$ were incubated in a $50 \mathrm{mM}$ Tris- $\mathrm{HCl}$ buffer, $\mathrm{pH}$ 7.4, containing $0.1 \%$ ascorbic acid, $4 \mathrm{mM} \mathrm{CaCl}, 10 \mu \mathrm{M}$ pargyline and $0.1 \mu \mathrm{M} 8-\mathrm{OH}$-DPAT for $30 \mathrm{~min}$ at $25^{\circ} \mathrm{C}$ with $30 \mathrm{nM}$ $\left[{ }^{3} \mathrm{H}\right] 5-\mathrm{HT}$ in the presence of increasing concentrations of $\mathrm{LiCl}(0.1 \mu \mathrm{M}$ to $100 \mathrm{mM})$. For rat brain membranes, 5$\mathrm{HT}_{1 \mathrm{E} / 1 \mathrm{~F}}$ binding was measured in the presence of $20 \mathrm{nM}$ 5-carboxytryptamine (5-CT). At the end of the incubation period, the tubes were cooled on ice and filtered under vacuum on Whatman GF/B glass fiber filters. Each filter was washed twice with $5 \mathrm{ml}$ of ice-cold incubation buffer and dried. The radioactivity retained on the filter was then measured by liquid scintillation counting. $5-\mathrm{HT}_{1 \mathrm{~B}}$ specific binding was determined by the difference between total $\left(5-\mathrm{HT}_{1 \mathrm{nonA}}\right)$ and $5-\mathrm{HT}_{1 \mathrm{E} / 1 \mathrm{~F}}$ bindings (Palacios et al. 1993).

\section{Saturation Experiments}

[25I] Cyanopindolol Binding. Rat brain membranes (25 $\mu \mathrm{g}$ of protein in $200 \mu \mathrm{l}$ of final volume) were incubated in a $10 \mathrm{mM}$ Tris- $\mathrm{HCl}$ buffer, $\mathrm{pH} 7.4$ containing $157 \mathrm{mM} \mathrm{NaCl}, 10 \mu \mathrm{M}$ pargyline, $0.1 \mu \mathrm{M}$ 8-OH-DPAT, and $30 \mu \mathrm{m}$ isoproterenol for $60 \mathrm{~min}$ at $37^{\circ} \mathrm{C}$ with in- creasing concentrations (20-500 pM) of [ $\left.{ }^{125} \mathrm{I}\right]$ cyanopindolol in the presence/absence of $1 \mathrm{mM} \mathrm{LiCl}$. Nonspecific binding was determined in the presence of $10 \mu \mathrm{M}$ of 5-HT. At the end of the incubation period, the tubes were cooled on ice and filtered under vacuum on Whatman GF/B glass fiber filters.

$\left[{ }^{3} \mathrm{H}\right] \mathrm{L694,247}$ Binding. Guinea pig brain membranes (500 $\mu \mathrm{g}$ of protein in a total volume of $1 \mathrm{ml}$ ) were incubated in a $50 \mathrm{mM}$ Tris- $\mathrm{HCl}$ buffer, $\mathrm{pH} \mathrm{7.4,} \mathrm{containing}$ $0.1 \%$ ascorbic acid, $4 \mathrm{mM} \mathrm{CaCl}_{2}$, and $10 \mu \mathrm{M}$ pargyline for $30 \mathrm{~min}$ at $25^{\circ} \mathrm{C}$ with increasing concentrations (20$500 \mathrm{pm}$ ) of $\left[{ }^{3} \mathrm{H}\right] \mathrm{L} 694,247$ in the absence or presence of 1 $\mathrm{mM} \mathrm{LiCl}$. Nonspecific binding was determined in the presence of $10 \mu \mathrm{M} 5-\mathrm{HT}$. Free and bound radioactivities were separated as previously described.

$\left[{ }^{3} \mathrm{H}\right] 5-\mathrm{HT}$ Binding. NIH 3T3 or CHO transfected cell membranes $(200 \mu \mathrm{g}$ of protein in a final volume of $1 \mathrm{ml})$ were incubated in a $50 \mathrm{mM}$ Tris- $\mathrm{HCl}$ buffer, $\mathrm{pH}$ 7.4, containing $0.1 \%$ ascorbic acid, $4 \mathrm{mM} \mathrm{CaCl}_{2}$, and $10 \mu \mathrm{M}$ pargyline for $30 \mathrm{~min}$ at $37^{\circ} \mathrm{C}$ with increasing concentrations $(1-40 \mathrm{nM})$ of $\left[{ }^{3} \mathrm{H}\right] 5-\mathrm{HT}$ with or without $1 \mathrm{mM} \mathrm{LiCl}$. Nonspecific binding was determined with $10 \mu \mathrm{M}$ of $5-\mathrm{HT}$. At the end of the incubation period, the tubes were cooled on ice and filtered as previously described.

\section{Pharmacological Specificity}

Each binding was measured in the presence/absence of $1 \mathrm{mM} \mathrm{LiCl}$. Binding of $\left[{ }^{3} \mathrm{H}\right] 5-\mathrm{HT}(30 \mathrm{~nm})$ to $5-\mathrm{HT}_{1 \mathrm{~B}}$, $5-\mathrm{HT}_{1 \mathrm{E} / 1 \mathrm{~F}}$ and 5-ht 6 receptors were performed as described above on rat brain $(250 \mu \mathrm{g} / \mathrm{ml})$ and CHO transfected cell $(200 \mu \mathrm{g} / \mathrm{ml})$ membranes, respectively.

Binding to $5-\mathrm{HT}_{1 \mathrm{~A}}$ receptor was carried out with $\left[{ }^{3} \mathrm{H}\right] 8-\mathrm{OH}-\mathrm{DPAT}(1 \mathrm{nM})$ on rat brain membranes under the experimental conditions used for $\left[{ }^{3} \mathrm{H}\right] 5-\mathrm{HT}$ binding. Nonspecific binding was determined with $10 \mu \mathrm{M}$ 5-HT.

Binding to cholinergic muscarinic receptors was determined with $\left[{ }^{3} \mathrm{H}\right] \mathrm{QNB}(3 \mathrm{nM})$ on rat brain membranes for $30 \mathrm{~min}$ at $25^{\circ} \mathrm{C}$ in a buffer composed of $50 \mathrm{mM}$ Tris$\mathrm{HCl} \mathrm{pH} \mathrm{7.4,} 120 \mathrm{mM} \mathrm{NaCl}$ and $50 \mathrm{mM} \mathrm{KCl}$. Nonspecific binding was measured in the presence of $10 \mu \mathrm{M}$ atropine.

Binding to $\beta$-adrenergic receptors was performed on rat brain membranes with $\left[{ }^{3} \mathrm{H}\right] \mathrm{DHA}(3 \mathrm{nM})$ in a $50 \mathrm{mM}$ Tris- $\mathrm{HCl}$ buffer $\mathrm{pH} 7.4$ containing $90 \mathrm{mM} \mathrm{NaCl}, 0.1 \mu \mathrm{M}$ 8-OH-DPAT and $30 \mu \mathrm{M}$ isoproterenol for $30 \mathrm{~min}$ at $25^{\circ} \mathrm{C}$. Nonspecific binding was determined with $10 \mu \mathrm{M}$ propranolol.

Uptake of 5-HT was conducted on rat brain synaptosomes $(500 \mu \mathrm{g} / \mathrm{ml})$. They were incubated for $15 \mathrm{~min}$ at $37^{\circ} \mathrm{C}$ in an oxygenated Krebs-Henseleit buffer $\mathrm{pH} 7.4$ $\left(125 \mathrm{mM} \mathrm{NaCl}, 3 \mathrm{mM} \mathrm{KCl}, 1 \mathrm{mM} \mathrm{NaH} \mathrm{PO}_{4}, 1.2 \mathrm{mM}\right.$ $\mathrm{CaCl}_{2}, 1.2 \mathrm{mM} \mathrm{MgSO}_{4}, 22 \mathrm{mM} \mathrm{NaHCO}, 0.01 \%$ ascorbic acid and $10 \mathrm{~mm}$ glucose) in the presence of $20 \mathrm{nM}$ $\left[{ }^{3} \mathrm{H}\right] 5-\mathrm{HT}$. Passive uptake was measured at $4^{\circ} \mathrm{C}$. Reactions were stopped by the addition of $2 \mathrm{ml}$ of ice-cold 
incubation buffer $\left(4^{\circ} \mathrm{C}\right)$ and rapid filtration through Whatman GF/B glass fiber filters.

\section{Specificity of Lithium versus Other Salts}

The effect of lithium on $\mathrm{h} 5 \mathrm{HT}_{1 \mathrm{~B}}$ receptors $(\mathrm{CHO}$ cell membranes) was compared to effects of other monovalent $\left(\mathrm{Cs}^{+}, \mathrm{Na}^{+}, \mathrm{Rb}^{+}, \mathrm{K}^{+}\right)$or divalent cations $\left(\mathrm{Mg}^{2+}\right.$, $\left.\mathrm{Mn}^{2+}, \mathrm{Zn}^{2+}, \mathrm{Sr}^{2+}\right)$. Briefly, $30 \mathrm{nM}$ of $\left[{ }^{3} \mathrm{H}\right] 5-\mathrm{HT}$ were incubated for $30 \mathrm{~min}$ at $25^{\circ} \mathrm{C}$ in the presence of $\mathrm{CHO}$ cell membranes $(250 \mu \mathrm{g} / 1 \mathrm{ml})$ and $1 \mathrm{mM}$ of the different cations (chloride salts). Nonspecific binding was determined in the presence of $10 \mu \mathrm{M} 5-\mathrm{HT}$.

\section{$\left[{ }^{35}\right.$ S $]$ GTP $\gamma$ S Binding}

Membranes $(20-50 \mu \mathrm{g})$ were incubated for $10 \mathrm{~min}$ at $25^{\circ} \mathrm{C}$ with increasing concentrations of $\mathrm{LiCl}(0.1 \mu \mathrm{M}$ to $10 \mathrm{mM}$ ) in a $20 \mathrm{mM}$ Hepes buffer $\mathrm{pH} 7.4$ containing 100 $\mathrm{mM} \mathrm{NaCl}, 3 \mathrm{mM} \mathrm{MgCl} 2,0.2 \mathrm{mM}$ ascorbic acid, $30 \mu \mathrm{M}$ GDP and $1 \mathrm{mM}$ of 1,10-phenanthroline. $0.1 \mu \mathrm{M}$ of 5-HT was then added for 20 minutes. $0.05 \mathrm{nM}$ of $\left[{ }^{35} \mathrm{~S}\right] \mathrm{GTP} \gamma \mathrm{S}$ was further added for $30 \mathrm{~min}$. Homogenates were then filtered under vacuum on Whatman GF/B glass fiber filters, as described previously.

\section{Adenylate Cyclase Activity}

The pellet of $\mathrm{h} 5-\mathrm{HT}_{1 \mathrm{~B}} \mathrm{CHO}$ transfected cells was resuspended $\left(100 \mu \mathrm{gml}^{-1}\right)$ and homogenized with a Potter apparatus in a $50 \mathrm{mM}$ Tris- $\mathrm{HCl}$ buffer $\mathrm{pH} 7.4\left(25^{\circ} \mathrm{C}\right)$. Dose-response curves of lithium were performed on the maximal inhibitory effect of 5-HT $(1 \mu \mathrm{M})$ on the Forskolin-stimulated adenylate cyclase activity in a final volume of $200 \mu l$. The incubation buffer was composed in a $50 \mathrm{mM}$ Tris- $\mathrm{HCl}$ buffer $\mathrm{pH} 7.4\left(25^{\circ} \mathrm{C}\right)$ containing $4 \mathrm{mM}$ $\mathrm{MgCl}_{2}, 0.2 \mathrm{mM}$ ATP, $20 \mu \mathrm{M}$ GTP, $20 \mathrm{mM}$ phosphocreatine, $0.2 \mathrm{mg} / \mathrm{ml}$ creatin-kinase, $30 \mu \mathrm{M}$ Forskolin, $2 \mathrm{mM}$ 3-isobutyl-1-methylxanthine, $1 \mu \mathrm{Ci}$ of $\left[\alpha^{32} \mathrm{P}\right] \mathrm{ATP}$ and $30,000 \mathrm{cpm}$ of $\left[{ }^{3} \mathrm{H}\right] \mathrm{cAMP}$ to quantify the recovery, the reaction being initiated by the addition of $50 \mu \mathrm{l}$ of the membrane preparation. After an incubation period of $10 \mathrm{~min}$ at $30^{\circ} \mathrm{C}$, the reaction was stopped by the addition of $200 \mu \mathrm{l}$ of a $50 \mathrm{mM}$ Tris- $\mathrm{HCl}$ buffer $\mathrm{pH} 7.4\left(4^{\circ} \mathrm{C}\right)$ containing $1 \%(\mathrm{w} / \mathrm{v})$ sodium dodecyl sulfate, $5 \mathrm{mM}$ cAMP and $5 \mathrm{mM}$ ATP. The amount of $\left[\alpha^{32} \mathrm{P}\right] \mathrm{cAMP}$ formed was separated by sequential chromatography on Dowex and alumina columns.

\section{Synaptosomal Release of $\left[{ }^{3} \mathrm{H}\right] 5-\mathrm{HT}$}

Rat brain synaptosomes $(500 \mu \mathrm{g} / \mathrm{ml})$ were loaded with $30 \mathrm{nM}\left[{ }^{3} \mathrm{H}\right] 5-\mathrm{HT}$ for $15 \mathrm{~min}$ at $37^{\circ} \mathrm{C}$ in an oxygenated Krebs-Henseleit buffer pH 7.4. The homogenate was washed twice by centrifugation $\left(17,500 \times \mathrm{g} / 5 \mathrm{~min} / 4^{\circ} \mathrm{C}\right.$, and the resulting pellet was resuspended in the same buffer. $200 \mu \mathrm{g}$ aliquots of the synaptosomal preparation were then dispatched in a 96-well filtration plate (glassfiber filter type B). CP 93,129 (0.1 $\mathrm{nM}$ to $1 \mu \mathrm{M}), \mathrm{LiCl}$ $(1 \mathrm{mM})$, or both, were then added and incubated for 5 min with the loaded synaptosomes. At the end of the incubation period, a 5-min $\mathrm{K}^{+}$stimulation $(15 \mathrm{mM})$ was applied. The 96 -well filtration plate was rapidly filtered, and the 96 filtrates were recovered and counted by liquid scintillation.

\section{Adenylate Cyclase Experiments on Human Blood Platelets}

Platelet preparation $\left(300,000 \mathrm{ml}^{-1}\right)$ was resuspended and tested under the experimental conditions previously described for cyclase asays. Dose-response curves of L694,247 (0.1 nM to $10 \mu \mathrm{M})$ were performed in the absence or presence of $\mathrm{LiCl}(0.01,0.1$, and $1 \mathrm{mM})$.

\section{Behavior}

The social interaction test was performed in mice (Francès 1988; Francès et al. 1990). Briefly, mice were either housed in groups of five animals or isolated for 1 week. They were tested in pairs (one grouped and one isolated), tested mice being placed under a transparent beaker inverted onto a rough surface glass plate. The number of escape attempts was counted for $2 \mathrm{~min}$ and defined as one of the following: (1) the forepaws were placed against the beaker wall; (2) the mouse sniffed at the rim of the beaker; or (3) the mouse scratched the glass floor. $\mathrm{LiCl}(2 \mathrm{mg} / \mathrm{kg}$ ) or sodium chloride (for control) were injected ICV (intracerebroventricular) $45 \mathrm{~min}$ before the test, and RU 24,969 (4 mg/ kg) was injected IP (intraperitoneally) $30 \mathrm{~min}$ before the test.

\section{Mathematical Analysis}

Binding experiments were analyzed under Prism 2.01 (GraphPad software, San Diego, CA), and statistical analyses were conducted using Student's $t$-test or twoway analysis of variance (ANOVA) performed under StatMate (GraphPad software, San Diego, CA).

\section{RESULTS}

\section{Molecular Interaction of Lithium with 5-HT $1 \mathrm{~B}$ Receptors}

Effect of Lithium on 5-HT ${ }_{1 B}$ Receptors. A series of experiments was carried out to establish displacement curves of lithium on $5-\mathrm{HT}_{1 \mathrm{~B}}$ binding at the full occupancy of receptor sites. This binding was measured in rat brain membranes using $\left[{ }^{3} \mathrm{H}\right] 5-\mathrm{HT}(30 \mathrm{nM})$ in the presence of $0.1 \mu \mathrm{M}$ 8-OH-DPAT to prevent binding to $5-\mathrm{HT}_{1 \mathrm{~A}}$ receptors, the nonsaturable binding being deter- 

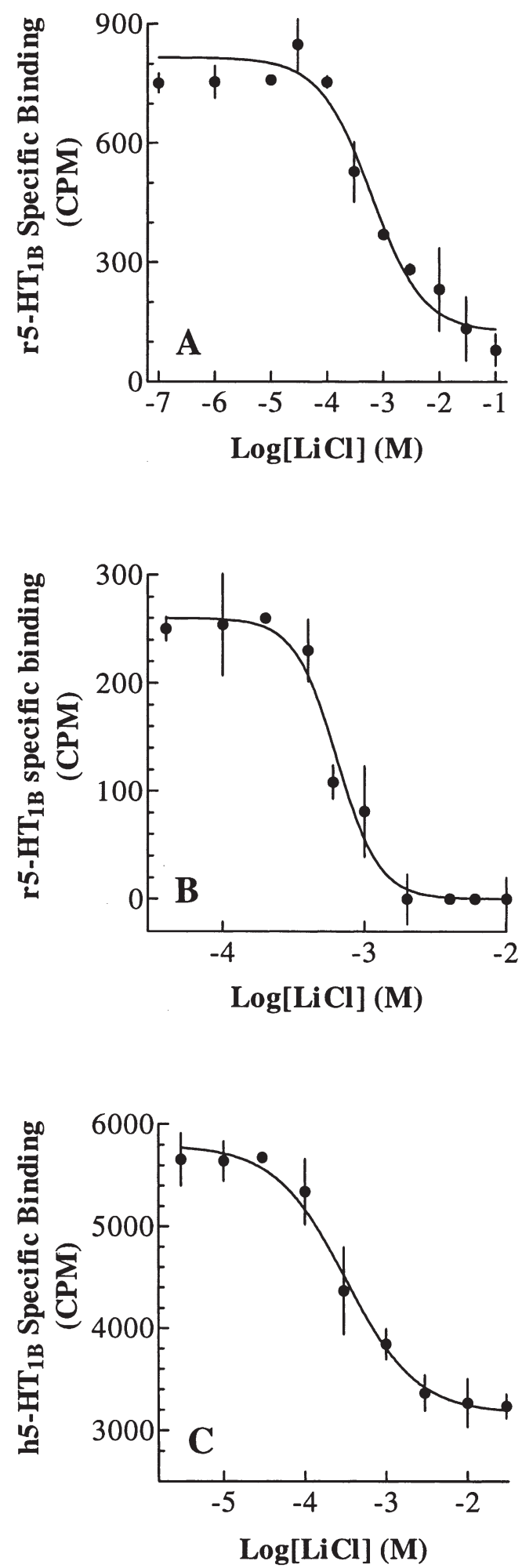

Figure 1. Effect of lithium on $5-\mathrm{HT}_{1 \mathrm{~B}}$ receptors. Dose response curve of lithium on $5-\mathrm{HT}_{1 \mathrm{~B}}$ receptors from either rat brain membranes (A), NIH3T3 transfected cells (B) or $\mathrm{CHO}$ transfected cells $(\mathrm{C})$. Each point is the mean \pm SEM of three independent experiments performed in triplicates. In all cases, $\mathrm{LiCl}$ totally inhibited this binding with an $\mathrm{IC}_{50}$ of $0.61 \pm 0.04 \mathrm{nM}, 0.64 \pm 0.01 \mathrm{nM}$ and $0.32 \pm 0.06 \mathrm{nM}$, respectively. $\mathrm{IC}_{50}$ are expressed in mean $\pm \mathrm{SD}$.

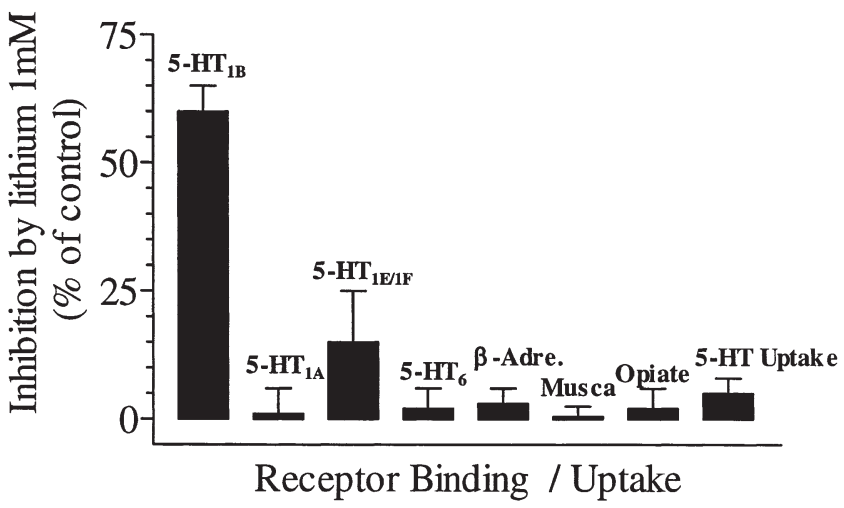

Figure 2. Pharmacological specificity of lithium's effect. Effect of lithium at a concentration of $1 \mathrm{mM}$ on different binding or 5-HT uptake. Results are expressed in percentage of inhibition as compared to control binding or uptake. Each bar represents the mean \pm SEM of three independent experiments performed in triplicate.

mined in the presence of $20 \mathrm{nM} / 5-\mathrm{CT}$. Under these experimental conditions, the difference between both bindings only represents $5-\mathrm{HT}_{1 \mathrm{~B}}$ specific binding (Palacios et al. 1993).

The obtained results evidenced a total inhibition of the binding of $\left[{ }^{3} \mathrm{H}\right] 5-\mathrm{HT}$ to $5-\mathrm{HT}_{1 \mathrm{~B}}$ receptors by lithium, the corresponding $\mathrm{IC}_{50}$ being in the millimolar range $(0.61 \pm 0.04 \mathrm{mM})$ (Figure $1 \mathrm{~A})$. This result was confirmed by using cells transfected with either the gene coding for the $\mathrm{r} 5-\mathrm{HT}_{1 \mathrm{~B}}$ receptor or the gene coding for the $\mathrm{h} 5-\mathrm{HT}_{1 \mathrm{~B}}$ receptors. These receptors are the species homologs of $5-\mathrm{HT}_{1 \mathrm{~B}}$ receptors (rat and human, respectively) and are characterized by differences not only in their aminoacid sequences but also in their pharmaco-

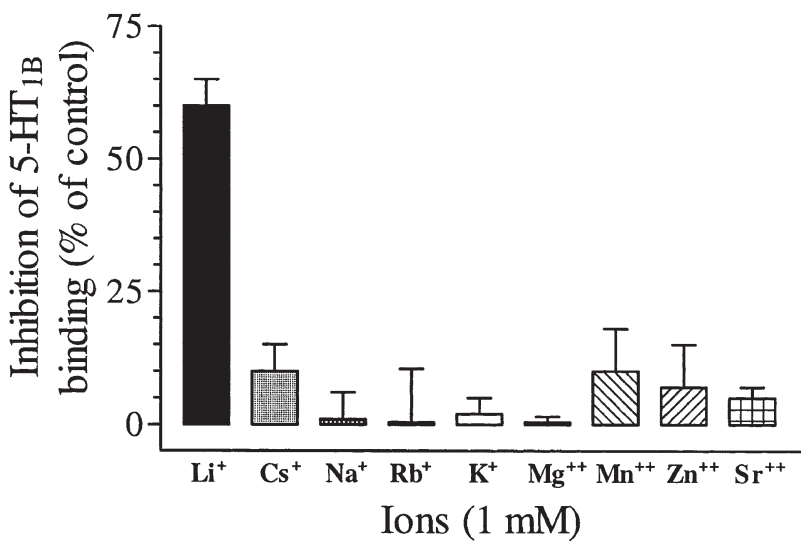

Figure 3. Effect of ions on 5- $\mathrm{HT}_{1 \mathrm{~B}}$-specific binding. Effect of lithium on $5-\mathrm{HT}_{1 \mathrm{~B}}$ receptors, as compared to the effect of other chloride cations $\left(\mathrm{Cs}^{+}, \mathrm{Na}^{+}, \mathrm{Rb}^{+}, \mathrm{K}^{+}, \mathrm{mg}^{2+}, \mathrm{Mn}^{2+}, \mathrm{Zn}^{+}\right.$, $\left.\mathrm{Sr}^{2+}\right)$, at a concentration of $1 \mathrm{mM}$. Each bar is the mean \pm SEM of two independent experiments performed in triplicates. Values are expressed in percentage of inhibition as compared to control binding. 

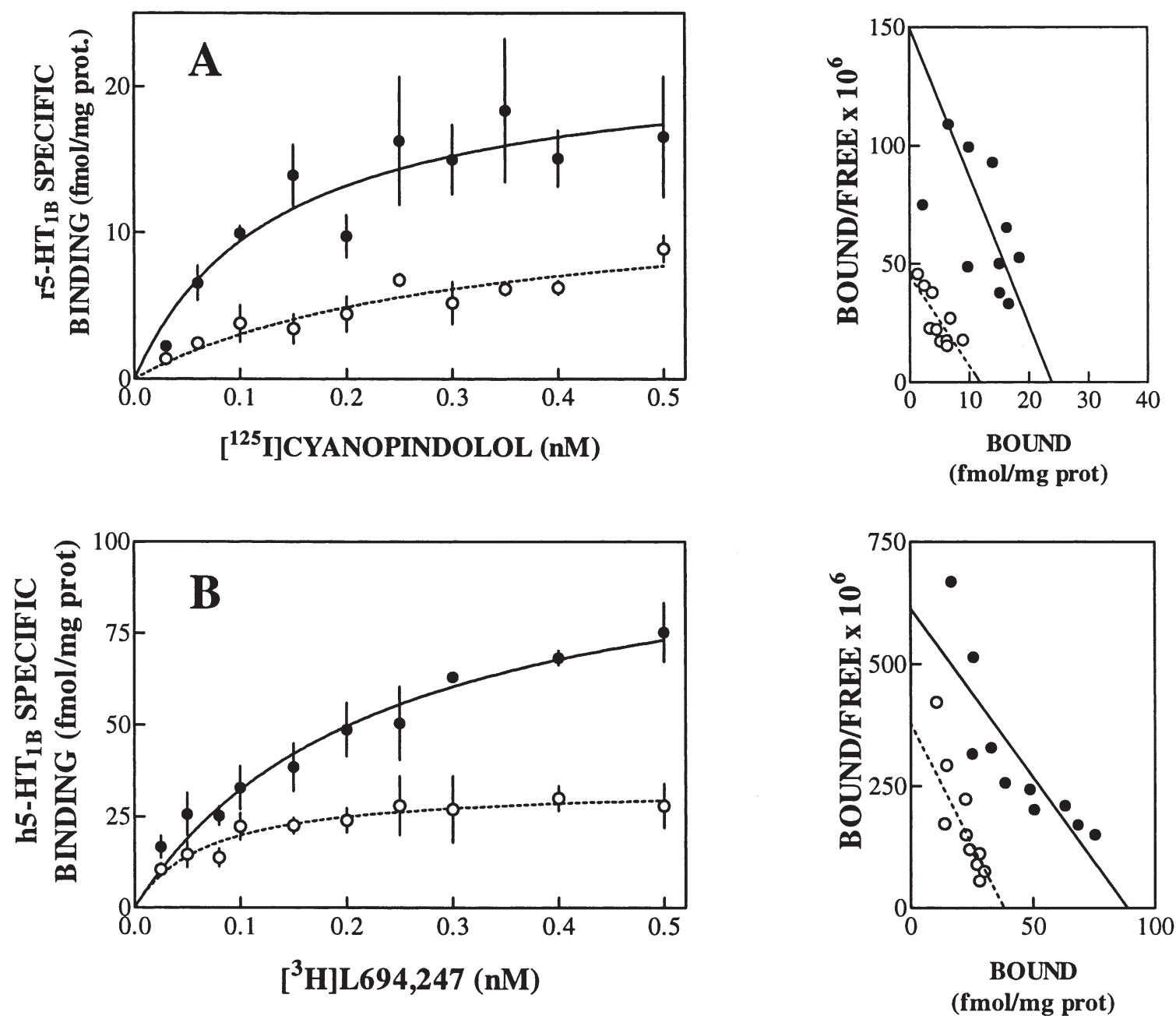

Figure 4. Interaction of lithium with $5-\mathrm{HT}_{1 \mathrm{~B}}$ receptors. $\mathrm{A}-\mathrm{r} 5-\mathrm{HT}_{1 \mathrm{~B}}$ : Binding of $\left[{ }^{125} \mathrm{I}\right]$ cyanopindolol $(20$ to $500 \mathrm{pM})$ to $\mathrm{r} 5-\mathrm{HT}_{1 \mathrm{~B}}$ receptors. Rat brain membranes $(25 \mu \mathrm{g})$ were incubated for $60 \mathrm{~min}$ at $37^{\circ} \mathrm{C}$. Nonspecific binding was determined in the presence of $10 \mu \mathrm{m}$ of 5-HT. B-h5-HT HB $_{1 \mathrm{~B}}$ Binding of [ $\left.{ }^{3} \mathrm{H}\right] \mathrm{L} 69,4247(20-500 \mathrm{pM})$ to h5-HT ${ }_{1 \mathrm{~B}}$ receptors. Guinea pig brain membranes $(500 \mu \mathrm{g})$ were incubated for $30 \mathrm{~min}$ at $25^{\circ} \mathrm{C}$. Nonspecific binding was determined in the presence of $10 \mu \mathrm{M} 5$ - HT. Experiments were carried out with $\left(\bigcirc_{-} \bigcirc\right)$ or without $(-0) 1 \mathrm{mM} \mathrm{LiCl}$. Each point is the mean \pm SEM of triplicate determinations of a typical experiment. This experiment was repeated three times. Right panels show the saturation curves and left panels represent their corresponding Scatchard plots (Scatchard 1949).

logical profiles (Hoyer et al. 1994). 5- $\mathrm{HT}_{1 \mathrm{~B}}$ binding to either cells was affected by lithium with similar $\mathrm{IC}_{50}(0.64 \pm$ 0.01 and $0.32 \pm 0.06 \mathrm{mM}$ for $\mathrm{r}$ and $\mathrm{h} 5-\mathrm{HT}_{1 \mathrm{~B}}$, respectively) (Figure 1B,C).

Effect of Lithium on Various Receptor Bindings. To assess the pharmacological specificity of this interaction, the effect of lithium was further tested on bindings to various other receptors including the other 5-HT autoreceptors $\left(\mathrm{r} 5-\mathrm{HT}_{1 \mathrm{~B}}\right.$ labeled with $\left[{ }^{3} \mathrm{H}\right] 5-\mathrm{HT}, 5-\mathrm{HT}_{1 \mathrm{~A}}$ labeled with $\left[{ }^{3} \mathrm{H}\right] 8-\mathrm{OH}-\mathrm{DPAT}, 5-\mathrm{HT}_{1 \mathrm{E} / 1 \mathrm{~F}}$ labeled with $\left[{ }^{3} \mathrm{H}\right] 5-\mathrm{HT}$ in the presence of $0.1 \mu \mathrm{M} 8-\mathrm{OH}-\mathrm{DPAT}$ and 20 nM 5-CT, 5-ht ${ }_{6}$ labeled with $\left[{ }^{3} \mathrm{H}\right] 5-\mathrm{HT}$ on $\mathrm{CHO} 5-\mathrm{ht}_{6}$ transfected cells) as well as nonserotonergic receptors (opiate receptors labeled with $\left[{ }^{3} \mathrm{H}\right]$ naloxone, cholinergic muscarinic receptors labeled with $\left[{ }^{3} \mathrm{H}\right] \mathrm{QNB}$ and $\beta$-adr- energic receptors labeled with $\left.\left[{ }^{3} \mathrm{H}\right] \mathrm{DHA}\right)$. This pharmacological analysis was also extended to the neuronal 5-HT transporter, measuring $\left[{ }^{3} \mathrm{H}\right] 5-\mathrm{HT}$ uptake in rat brain synaptosomes. None of these bindings was significantly affected by lithium, at $1 \mathrm{mM}$, a concentration that inhibited $60 \pm 5 \%$ of the control $5-\mathrm{HT}_{1 \mathrm{~B}}$ binding. At the same concentration, lithium was neither able to alter the neuronal 5-HT uptake (Figure 2).

Effect of Other Cations on 5-HT ${ }_{1 B}$ Receptors. The ionic specificity of this effect also was investigated studying the potential interaction of various monovalent $\left(\mathrm{Li}^{+}\right.$, $\left.\mathrm{Na}^{+}, \mathrm{Cs}^{+}, \mathrm{K}^{+}, \mathrm{Rb}^{+}\right)$or divalent cations $\left(\mathrm{Co}^{++}, \mathrm{Mg}^{++}\right.$, $\mathrm{mn}^{++}, \mathrm{Zn}^{++}, \mathrm{Sr}^{++}$) with $5-\mathrm{HT}_{1 \mathrm{~B}}$ binding. None of the cations studied, at $1 \mathrm{mM}$, altered the binding of $\left[{ }^{3} \mathrm{H}\right] 5-$ $\mathrm{HT}$ to $5-\mathrm{HT}_{1 \mathrm{~B}}$ receptors; whereas, lithium, at the same 

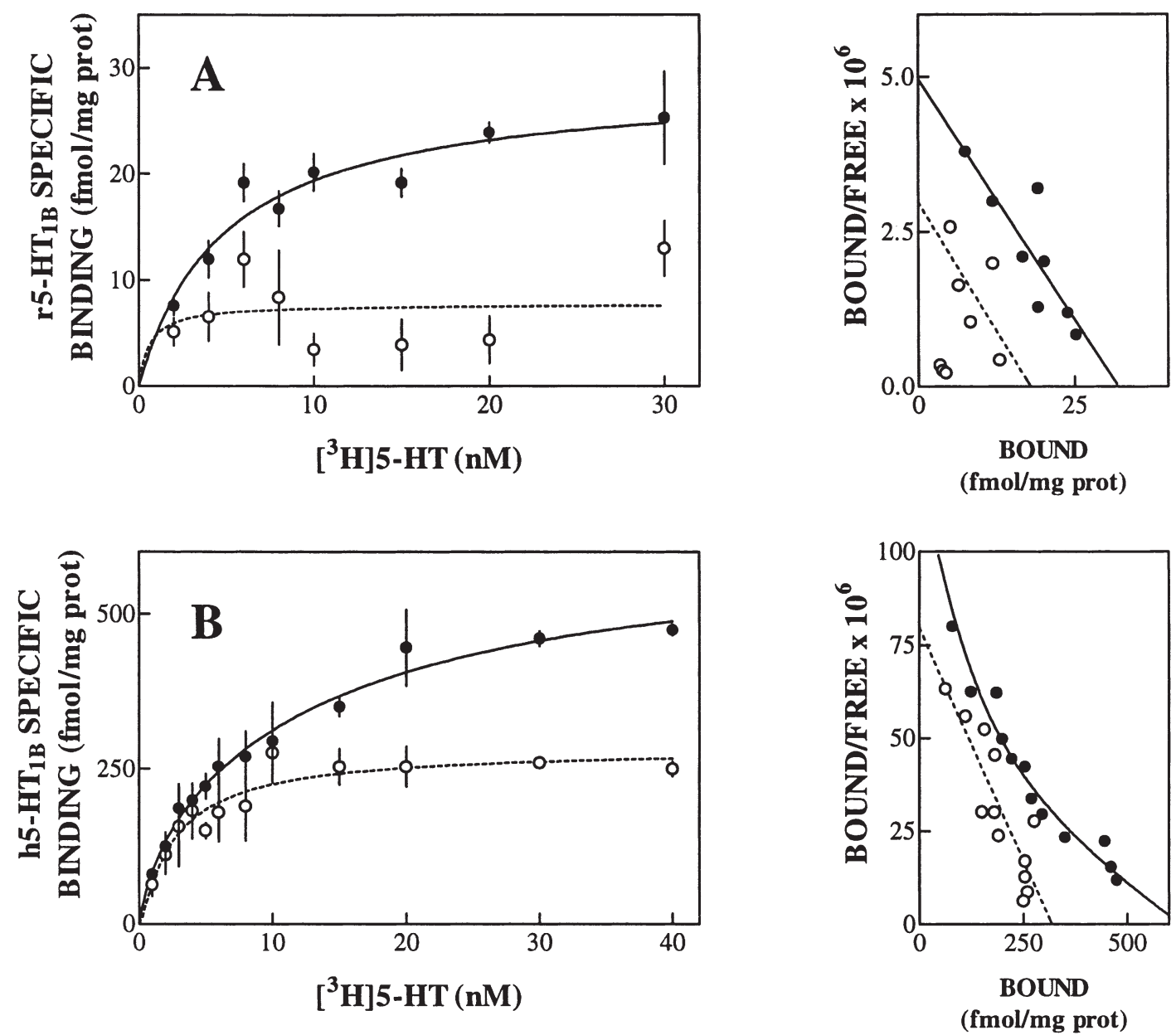

Figure 5. Interaction of lithium with $5-\mathrm{HT}_{1 \mathrm{~B}}$ receptors. $\mathrm{A}-\mathrm{r} 5-\mathrm{HT}_{1 \mathrm{~B}}$ : Binding of $\left[{ }^{3} \mathrm{H}\right] 5-\mathrm{HT}$ (1 to $\left.30 \mathrm{nM}\right)$ to $\mathrm{r} 5-\mathrm{HT} \mathrm{T}_{1 \mathrm{~B}}$ receptors in NIH 3T3 transfected cells. Cells membranes. $(200 \mu \mathrm{g})$ were incubated for $30 \mathrm{~min}$ at $25^{\circ} \mathrm{C}$. Nonspecific binding was determined in the presence of $10 \mu \mathrm{M}$ of 5-HT. B-h5-HT $1 \mathrm{~B}$ : Binding of $\left[{ }^{3} \mathrm{H}\right] 5-\mathrm{HT}(1-40 \mathrm{nM})$ to h5-HT $\mathrm{H}_{1 \mathrm{~B}}$ receptors in CHO transfected cells. Cell membranes $(200 \mu \mathrm{g})$ were incubated for $30 \mathrm{~min}$ at $25^{\circ} \mathrm{C}$. Nonspecific binding was determined in the presence of 10 $\mu \mathrm{M}$ 5-HT. Experiments were carried out with $\left(\mathrm{O}_{-} \mathrm{O}\right)$ or without $(\bullet-\bullet) 1 \mathrm{mM} \mathrm{LiCl}$. Each point is the mean \pm SEM of triplicate determinations of a typical experiment. This experiment was repeated three times. Right panels show the saturation curves, and left panels represent their corresponding Scatchard plots (Scatchard 1949).

concentration, prevented $60 \pm 5 \%$ of this binding (Figure 3).

Analysis of the Inhibitory Effect of Lithium on 5-HT Receptors. The molecular mechanism underlying this interaction of lithium has been studied performing saturation curves of $\left[{ }^{3} \mathrm{H}\right] 5-\mathrm{HT}$ on the two species homologous of $5-\mathrm{HT}_{1 \mathrm{~B}}$ receptor ( $\mathrm{r} 5-\mathrm{HT}_{1 \mathrm{~B}}$ and $\left.\mathrm{h} 5-\mathrm{HT}_{1 \mathrm{~B}}\right)$. In brain, specific radioligands were used; whereas, in transfected cells, $\left[{ }^{3} \mathrm{H}\right] 5-\mathrm{HT}$ was selected to label the sole expressed receptor. Analysis of the saturation curves and their Scatchard plots (Scatchard 1949) showed that $B_{\max }$ values for $\left[{ }^{125} \mathrm{I}\right]$ cyanopindolol, $\left[{ }^{3} \mathrm{H}\right] \mathrm{L} 694,247$, and $\left[{ }^{3} \mathrm{H}\right] 5-\mathrm{HT}$, were markedly reduced in the presence of $1 \mathrm{mM} \mathrm{LiCl}$ (about 50\%); whereas, $\mathrm{Kd}$ values were not significantly affected (Figures 4 and 5). Parallel Scatchard plots of the saturation curves clearly indicated that the interaction of lithium did not correspond to a competitive inhibition but rather suggested that it likely corresponded to a noncompetitive phenomenon (Figures 4 and 5).

\section{Functional Interaction of Lithium with 5-HT $1 \mathrm{~B}$ Receptors}

Effect of lithium on $\left[{ }^{35} S\right] G T P \gamma S$ Binding. The question of the functional relevance of the observed molecular interaction was also addressed using different experimental paradigms. A first series of assays consisted of testing the ability of lithium to interact with the second messenger system related to $5-\mathrm{HT}_{1 \mathrm{~B}}$ receptors; that is, the adenylate cyclase. Indeed, $5-\mathrm{HT}_{1 \mathrm{~B}}$ receptors can couple to Gi proteins and their activation can lead to an inhibition of the adenylate cyclase activity (Hoyer et al. 1994; Thomas et al. 1995). 

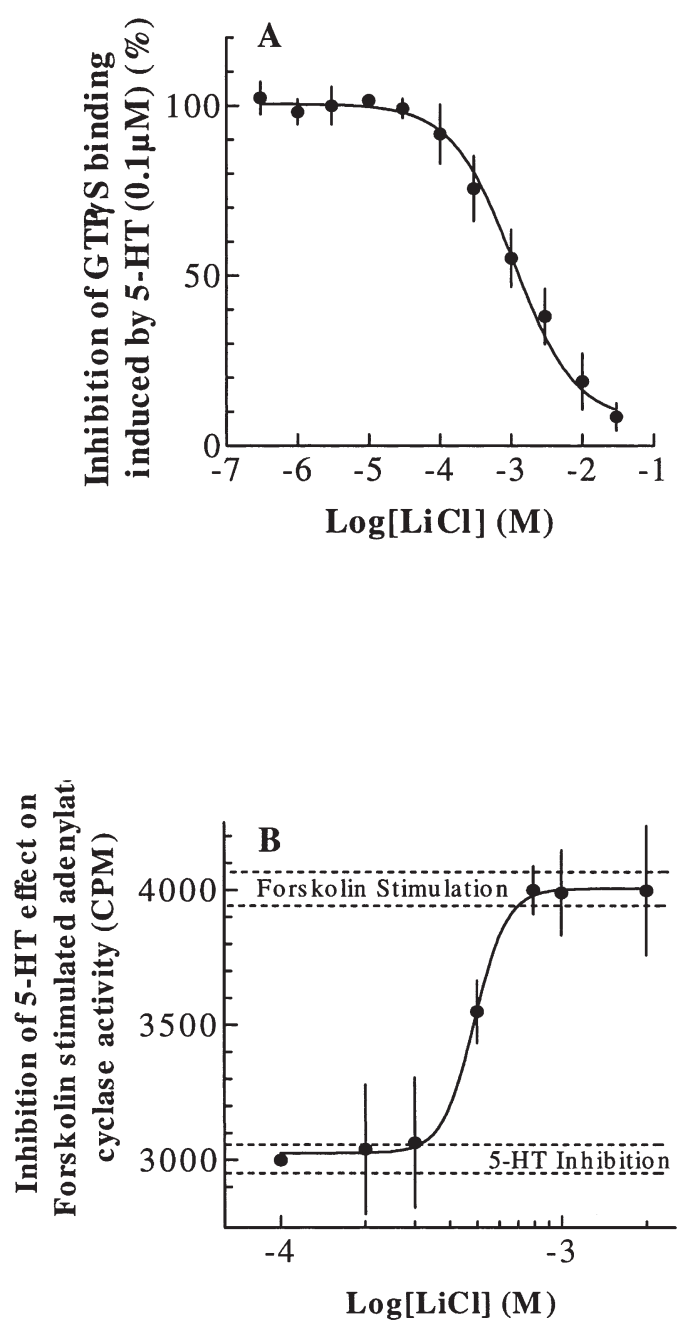

Figure 6. Effect of lithium on the second messenger coupled to $5-\mathrm{HT}_{1 \mathrm{~B}}$ receptors. (A) Effect on 5- $\mathrm{HT}_{1 \mathrm{~B}}$ coupled G-protein ([ $\left.{ }^{35} \mathrm{~S}\right] \mathrm{GTP} \gamma \mathrm{S}$ binding): Increasing concentrations of lithium were tested on the $\left.{ }^{35} \mathrm{~S}\right] \mathrm{GTP} \gamma \mathrm{S}$ binding after a stimulation of $\mathrm{CHO}$ h5- $\mathrm{HT}_{1 \mathrm{~B}}$ transfected cells by 5 -HT $(0.1 \mu \mathrm{M})$. Basal binding of $\left[{ }^{35} \mathrm{~S}\right] \mathrm{GTP} \gamma \mathrm{S}$ was measured in the absence of 5-HT and nonspecific binding was determined in the presence of $10 \mu \mathrm{M}$ GTP $\gamma$ S. The activation by $0.1 \mu \mathrm{M} 5-\mathrm{HT}$ corresponds to $144 \pm$ $4 \%$ of the basal value ( $76 \pm 4 \%$ of the maximal stimulation). Each point is the mean \pm SEM of three independent experiments performed in triplicates. $100 \%$ usually represents about $2000 \mathrm{cpm}$. Lithium inhibited this activation with an $\mathrm{IC}_{50}$ of $1.09 \pm 0.01 \mathrm{mM}$ (mean $\pm \mathrm{SD}$ ). (B) Effect on $5-\mathrm{HT}_{1 \mathrm{~B}}$ coupled adenylate cyclase activity: Increasing concentrations of lithium were tested on the effect of $1 \mu \mathrm{M}$ 5-HT on the Forskolin stimulated adenylate cyclase activity coupled to $5-\mathrm{HT}_{1 \mathrm{~B}}$ receptors. Under these conditions, Forskolin $(10 \mu \mathrm{M})$ promoted a 10-fold stimulation of the basal adenylate cyclase activity (the basal level represents $612 \pm 58 \mathrm{cpm}$, and the Forskolin-stimulated was $6542 \pm 124 \mathrm{cpm}) .1 \mu \mathrm{M} 5-\mathrm{HT}$ reduced this activation by $30 \pm 6 \%$ and lithium inhibited this 5 -HT effect with an $\mathrm{IC}_{50}$ of $0.49 \pm 0.02 \mathrm{mM}$ (mean $\pm \mathrm{SD}$ ).

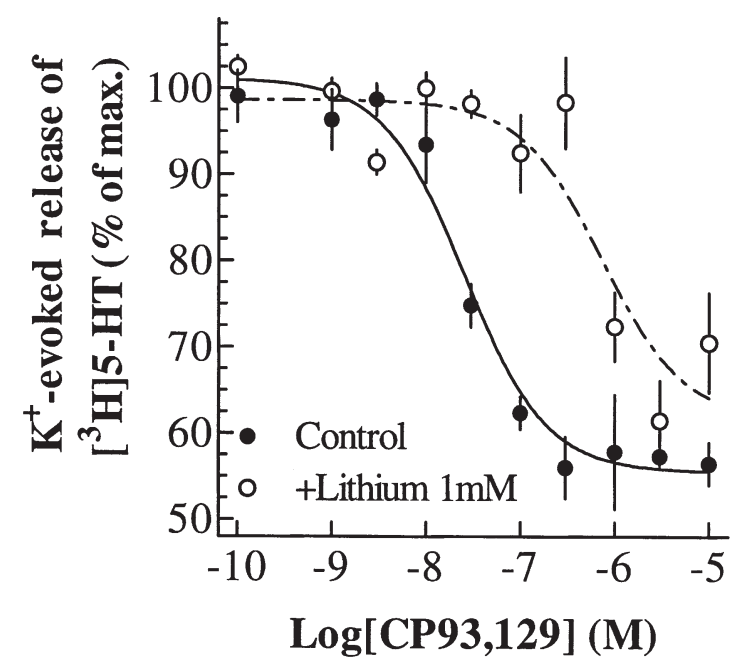

Figure 7. Effect of lithium on the synaptosomal release of 5-HT. Rat brain synaptosomes were loaded with $20 \mathrm{~nm}$ $\left[{ }^{3} \mathrm{H}\right] 5-\mathrm{HT}$. A 5-min $\mathrm{K}+$ stimulation was applied. Experiments were carried out with $(\bigcirc-\bigcirc)$ or without $(\bullet-\bullet) 1 \mathrm{mM}$ $\mathrm{LiCl}$. Each point is the mean \pm SEM of three independent experiments performed in triplicate. The maximum evoked release of 5-HT usually represents $1000 \mathrm{cpm}$. CP93,129 dose dependently inhibited this release $(25.7 \pm 0.7 \mathrm{mM})$ with a maximal effect of $44 \pm 5 \%$. In the presence of $1 \mathrm{mM}$ lithium, the $\mathrm{IC}_{50}$ of CP93, 129 was increased to of $631 \pm 53 \mathrm{mM}$ (mean \pm SD). Two-way ANOVA demonstrated the significant effect of lithium on the effect of CP93,129 on the synaptosomal release of 5-HT, $\mathrm{F}(1,31)=47.54, p=.0002$.

Using the binding of $\left[{ }^{35} \mathrm{~S}\right] \mathrm{GTP} \gamma \mathrm{S}$ as an index of the coupling of the receptor to the G-protein, it was observed, as expected, that $\mathrm{CP} 93,129$, a $5-\mathrm{HT}_{1 \mathrm{~B}}$-specific agonist, actually increased the $\left[{ }^{35} \mathrm{~S}\right] \mathrm{GTP} \gamma \mathrm{S}$ binding and, thus, the coupling of the receptor with the G-protein (Thomas et al. 1995; Pauwels et al. 1997). Indeed, the binding of $\left.{ }^{35} \mathrm{~S}\right] \mathrm{GTP} \gamma \mathrm{S}$ in $\mathrm{CHO}$ cells expressing $\mathrm{h} 5-\mathrm{HT}_{1 \mathrm{~B}}$ receptor was increased in the presence of 5-HT in a dose-dependent manner with a maximal effect of $164 \pm$ $3 \%$ (versus basal level) and an $\mathrm{EC}_{50}$ of $27 \pm 5 \mathrm{nM}$ (data not shown). After enhancing the $\left[{ }^{35} \mathrm{~S}\right] \mathrm{GTP} \gamma \mathrm{S}$ binding with 5 - $\mathrm{HT}(0.1 \mu \mathrm{M})$ on h5- $\mathrm{HT}_{1 \mathrm{~B}} \mathrm{CHO}$ transfected cells, (76 $\pm 4.8 \%$ of the maximal increase), it was shown that lithium dose dependently antagonized this 5-HT-induced coupling with an $\mathrm{EC}_{50}$ of $1.09 \pm 0.01 \mathrm{mM}$, a value close to that observed in binding studies (Figure 6A).

Moreover, this result was confirmed in assays directly measuring the enzyme (adenylate cyclase) activity. The effect of lithium was determined on the inhibitory activity of 5-HT $(1 \mu \mathrm{M})$ on the cAMP formation primarily induced by Forskolin in $\mathrm{h} 5-\mathrm{HT}_{1 \mathrm{~B}} \mathrm{CHO}$ transfected cells where lithium was also able to inhibit this activity with a similar $\mathrm{EC}_{50}(0.49 \pm 0.02 \mathrm{mM})$, (Figure $6 \mathrm{~B}$ ). 


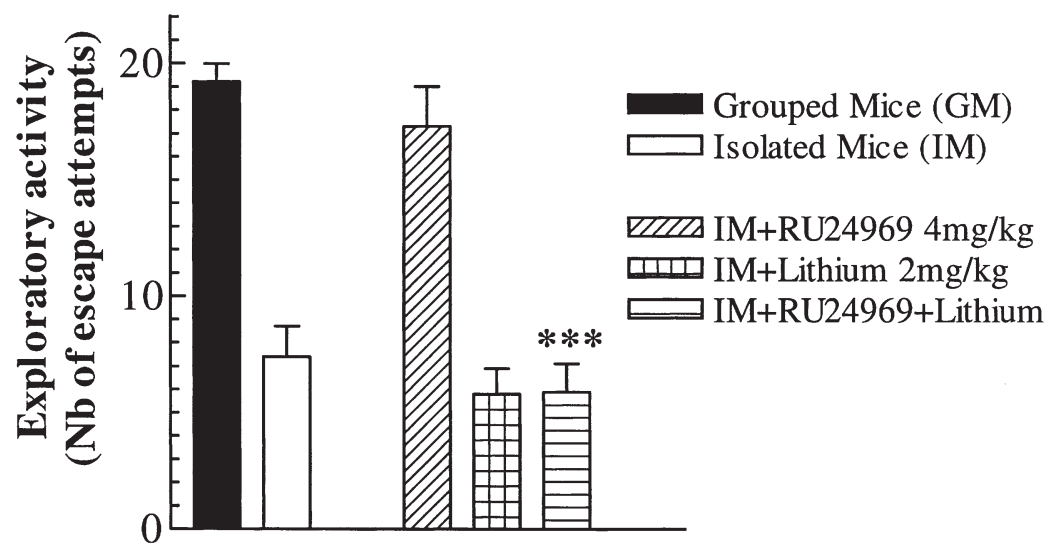

Figure 8. Effect of lithium on the social interaction test in mice. The social interaction test was performed in mice (Francès 1988), measuring the number of escape attempts of isolated treated mice. Results are expressed as the mean \pm SEM of escape attempts per mouse from three independent experiments. In each series, five mice were tested in each group, and each mouse was tested only once. Statistical analysis were conducted using Student'st-test where ${ }^{* * *}$ corresponds to $p<.001$. Isolated mice presented a behavioral deficit revealed by the reduction of the number of escape attempts (19.2 \pm 0.78 escape attempts for grouped mice vs. $7.4 \pm 1.3$ for isolated mice). This deficit was reversed by RU24,969 (17.3 \pm 1.7 escape attempts), and $\mathrm{LiCl}$ suppressed the RU24, 969's effect (5.9 \pm 1.2 escape attempts); whereas, it had no significant effect on its own (5.8 \pm 1.1 escape attempts).

[ ${ }^{3}$ H]5-HT Synaptosomal Release. The next step addressed in our study resulted from the cascade of the physiological events mediated by $5-\mathrm{HT}_{1 \mathrm{~B}}$ receptor activation; that is, control of the neuronal release of 5-HT at the synaptic level.

Release experiments were carried out using rat cortical synaptosomes previously loaded with $\left[{ }^{3} \mathrm{H}\right] 5-\mathrm{HT}$. Under these conditions, a $5-\mathrm{HT}_{1 \mathrm{~B}}$ agonist $(\mathrm{CP93}, 129)$ promoted, in a dose-dependent manner, a $44 \pm 5 \%$ inhibition of the $\mathrm{K}^{+}$-evoked release of the tritiated amine with an $\mathrm{IC}_{50}$ value of $25.7 \pm 0.7 \mathrm{nM}$. $\mathrm{LiCl}$, at $1 \mathrm{mM}$, partially reversed the latter inhibitory effect, because the $\mathrm{IC}_{50}$ of CP93,129 was shifted to $631 \pm 53 \mathrm{nM}$ (Figure 7).

Behavioral Studies. To test the effect of lithium in an in vivo situation, behavioral studies were performed using a test previously shown to be $5-\mathrm{HT}_{1 \mathrm{~B}}$-specific: the social interaction test in mice (Francès 1988; Francès et al. 1990). Mice were isolated for 1 week to induce a behavioral change characterized by a deficit in the exploratory activity of the animals when placed in the presence of a congener: $62 \%$ reduction of the number of escape attempts $(19.2 \pm 0.78$ escape attempts for grouped mice vs. $7.4 \pm 1.3$ for isolated mice). The administration of a $5-\mathrm{HT}_{1 \mathrm{~B}}$ agonist (RU24,969; $4 \mathrm{mg} / \mathrm{kg}$ ) to isolated mice totally abolished this deficit $(17.3 \pm 1.7$ escape attempts) and the injection of lithium $(2 \mathrm{mg} / \mathrm{kg})$ was able to prevent the latter $5-\mathrm{HT}_{1 \mathrm{~B}}$ mediated effect (5.9 \pm 1.2 escape attempts); whereas, it had no significant effect on its own (5.8 \pm 1.1 escape attempts) (Figure 8).

\section{Interaction of Lithium with 5- $\mathrm{HT}_{1 \mathrm{~B}}$ Receptors in Humans: Effect on 5-HT ${ }_{1 \mathrm{~B}}$ Cyclase-Dependent Activity in Human Blood Platelet.}

Further investigations were conducted to examine whether or not these results could also apply to the clinical field. Studies were carried out on human blood platelets, which contain $5-\mathrm{HT}_{1 \mathrm{~B}}$ receptors (unpublished results). In this preparation, the activity of $5-\mathrm{HT}_{1 \mathrm{~B}}$ receptors was determined by measuring adenylate cyclase activity in the presence/absence of lithium.

Under these conditions, Forskolin $(10 \mu \mathrm{M})$ promoted a 10-fold simulation of the basal adenylyl cyclase activity (measured by the cAMP formation) and L694,247, a $\mathrm{h} 5-\mathrm{HT}_{1 \mathrm{~B}}$ agonist, dose dependently reduced this activation with an $\mathrm{EC}_{50}$ value of $32.5 \mathrm{nM}$ and a maximal effect of $15 \%$. LiCl, at various concentrations ranging from 10 $\mu \mathrm{M}$ to $10 \mathrm{mM}$, was able to reverse this effect dose dependently and, at $1 \mathrm{mM}, \mathrm{LiCl}$ totally abolished the L694,247 activity (Figure 9).

\section{DISCUSSION}

The experimental work presented here demonstrates that lithium has the capacity to interact specifically with $5-\mathrm{HT}_{1 \mathrm{~B}}$ receptors at concentrations ranging from 0.5 to 1 $\mathrm{mM}$. This interaction seems to be ion and receptor specific. It is noteworthy that the human homolog of the 5$\mathrm{HT}_{1 \mathrm{~B}}$ receptors is also sensitive to lithium within the same concentration range. In terms of biochemical 


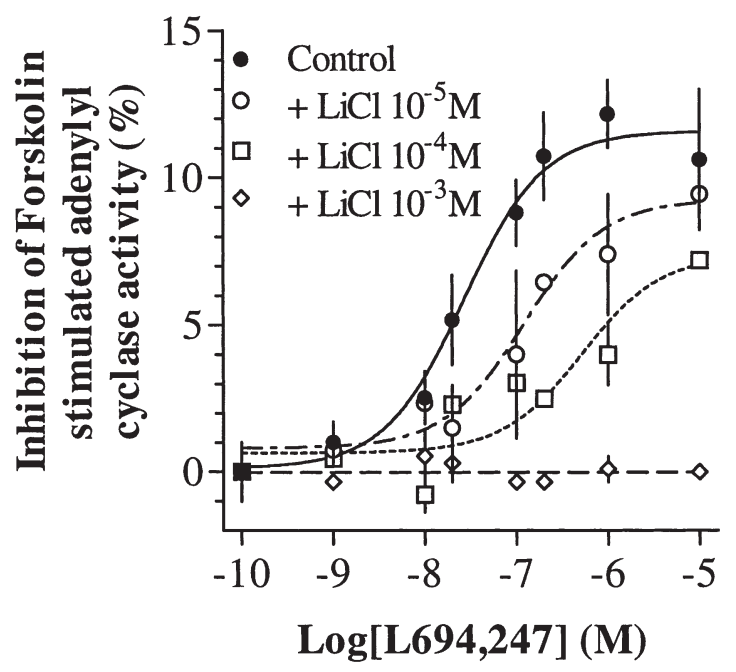

Figure 9. Effect of lithium on $5-\mathrm{HT}_{1 \mathrm{~B}}$ receptors in human blood platelets. Adenylate cyclase activity was measured in human blood platelets by determining the $\left[{ }^{32} \mathrm{P}\right] \mathrm{cAMP}$ formation. Experiments were performed with $0.01 \mathrm{mM} \mathrm{LiCl}\left(\bigcirc_{-}\right.$ $\bigcirc), 0.1 \mathrm{mM} \mathrm{LiCl}(\square-\square), 1 \mathrm{mM} \mathrm{LiCl}(\diamond-\diamond)$ and without $\mathrm{LiCl}(-)$ ). Data are expressed as percentage of the maximal effect. Each point is the mean \pm SEM of eight independent experiments performed in triplicate. Under these conditions, Forskolin $(10 \mu \mathrm{M})$ promoted a 10 -fold stimulation of the basal adenylate cyclase activity (the basal level represent $155 \pm 29 \mathrm{cpm}$, and the Forskolin-stimulated is $1475 \pm$ $238 \mathrm{cpm}$ ). L694,247 dose dependently reduced this activation with an $\mathrm{EC}_{50}$ of $27 \pm 6 \mathrm{nM}$. Two-way ANOVA demonstrated the significant effect of lithium on the effect of L694,247 on the Forskolin stimulated adenylate cyclase: $F(1,50)=140.53$, $p<.0001$ for the interaction of $1 \mathrm{mM}$ lithium. $\mathrm{F}(1,43)=5.34$, $p=.0257$ for the interaction of $0.1 \mathrm{mM}$ lithium. $\mathrm{F}(1,38)=$ $0.18, p=.6699$ for the interaction of $0.01 \mathrm{mM}$ lithium.

mechanism, it corresponds to a noncompetitive inhibition (parallel Scatchard plots), suggesting that lithium probably acts on a site distinct from that binding 5-HT, although located on the $5-\mathrm{HT}_{1 \mathrm{~B}}$ receptor protein. The interaction of lithium with $5-\mathrm{HT}_{1 \mathrm{~B}}$ receptors was revealed at every level of the functioning of the receptor. This was shown at the molecular level (binding studies) and at the functional level, in studies dealing either with the effector system coupled to $5-\mathrm{HT}_{1 \mathrm{~B}}$ receptors $\left(\left[{ }^{35} \mathrm{~S}\right] \mathrm{GTP} \gamma \mathrm{S}\right.$ binding and adenylate cyclase assays) or with the cellular function of the $5-\mathrm{HT}_{1 \mathrm{~B}}$ receptors (release experiments) and in the in vivo situation.

These results strengthen the hypothesis that the serotonergic terminal autoreceptor $\left(5-\mathrm{HT}_{1 \mathrm{~B}}\right)$ actually constitutes a direct molecular target for lithium. This conclusion is also supported by the findings of Redrobe and Bourin (Redrobe and Bourin 1999), who demonstrated that, in the mouse forced swimming test, lithium promotes an antidepressant-like effect, in reducing the im- mobility time of the animals, presumably by acting on $5-\mathrm{HT}_{1 \mathrm{~B}}$ receptors.

From a clinical point of view, it is of interest to underline that the action of lithium on $5-\mathrm{HT}_{1 \mathrm{~B}}$ receptors is also observed in human materials, not only in vitro on $\mathrm{h} 5-\mathrm{HT}_{1 \mathrm{~B}}$ transfected cells but also ex vivo, in human blood platelets. Thus, these experiments strongly suggest that the interaction of lithium with $5-\mathrm{HT}_{1 \mathrm{~B}}$ receptors, observed in animal material as well as in cells transfected with animal or human genes, is likely to be extended to human tissue. Moreover, this effect occurs at concentrations of lithium $(0.1-1 \mathrm{mM})$, which correlates well with the relevant therapeutic concentrations attained in the brain of patients (Schildkraut 1973; Schou and Thomsen 1975; Price et al. 1990; Odagaki et al. 1992; Schou 1997; Gershon and Soares 1997; Soares and Gershon 1998).

The fact that the therapeutic effect of lithium is generally observed after 2-3 of weeks treatment; whereas, the biochemical effect of the ion on $5-\mathrm{HT}_{1 \mathrm{~B}}$ receptor desensitization is rapid, does not preclude the involvement of $5-\mathrm{HT}_{1 \mathrm{~B}}$ receptors as primary targets for the relevant therapeutic effect of lithium. Indeed, the increase of serotonergic activity, rapidly induced by lithium, presumably leads to a cascade of mechanisms of regulation responsible for the final therapeutic activity of lithium occurring after a delay. Indeed, a very similar situation is observed with SSRI.

When the clinical effect of a drug is observed after a chronic treatment, it can be hypothesized that this effect is the result of a new homeostasis in the brain induced by its primarily direct action, which leads either directly or indirectly to the final observed effect. Because very few studies have dealt with the acute effect of lithium, it was of interest to define its direct molecular action (primarily targets). Thus, the interaction of lithium with $5-\mathrm{HT}_{1 \mathrm{~B}}$ receptors, shown in this series of experiments, may explain some of its clinical properties. In particular, reported beneficial effects observed in mood disorders may, at least partly, originate from the ability of lithium to facilitate the serotonergic transmission known to be altered in these pathologies (Price et al. 1990; Siever et al. 1991; Grahame-Smith 1992; Odagaki et al. 1992). Indeed, the desensitization of $5-\mathrm{HT}_{1 \mathrm{~B}}$ autoreceptors, induced by lithium, results in a decrease of the efficacy of the negative retrocontrol of the 5-HT release at neurone terminals, leading to an increase of the release of 5-HT, and thus, to an enhancement of the availability of 5-HT in the synaptic cleft. This mechanism is in agreement with previous observations showing that lithium has the capacity to enhance 5-HT efflux at nerve terminals (Green and Grahame-Smith 1976; Treiser et al. 1981; Blier and de Montigny 1985; Hotta et al. 1986; Blier et al. 1987; Friedman and Wang 1988; Wang and Friedman 1988; Hotta and Yamawaki 1988; Hide and Yamawaki 1989; Sharp et al. 1991) and could 
also account for the increased benefit in the therapeutic action of antidepressant drugs when associated with lithium (de Montigny et al. 1983; Cowen et al. 1991; Baumann et al. 1996).Antidepressants, particularly SSRIs, promote enhancement of the availability of 5-HT at the synaptic level by blocking the reuptake of the amine (Hyttel 1982; Owen et al. 1997), and lithium seems to have a similar effect by reducing the $5-\mathrm{HT}_{1 \mathrm{~B}}$ auto receptor activity. Thus, a kind of synergism between lithium and antidepressants may significantly enhance the serotonergic activity in treated patients.

In conclusion, $5-\mathrm{HT}_{1 \mathrm{~B}}$ receptors constitute a newly identified molecular target for lithium. In this regard, this result opens new insights in the field of psychiatric research. First, it should substantially enhance our understanding of the biology of mania, manic depressive illness, aggression, and suicidal behavior, which are all markedly affected by lithium; and, second, it should facilitate development of alternative treatment or elaboration of novel promising therapeutic agents, because lithium is a very valuable drug, but one with substantial side-effects and a very low therapeutic safety index (Schildkraut 1973; Schou and Thomsen 1975; Wood and Goodwin 1987; Price et al. 1990; Odagaki et al. 1992; Price and Heninger 1994; Schou 1997; Gershon and Soares 1997; Soares and Gershon 1998).

\section{ACKNOWLEDGMENTS}

$\mathrm{NIH} 3 \mathrm{~T} 3$ cells transfected with the $\mathrm{r} 5-\mathrm{HT}_{1 \mathrm{~B}}$ receptor gene and transfected $\mathrm{CHO}$ cells expressing the $\mathrm{h} 5-\mathrm{HT}_{1 \mathrm{~B}}$ receptor were kindly given by René Hen. Transfected $\mathrm{CHO}$ cells expressing the $5-$ ht $_{6}$ or receptor were given by Jean-Charles Schwartz.

\section{REFERENCES}

Attack JR (1996): Inositol monophosphatase, the putative therapeutic target for lithium. Brain Res Rev 22:183-190

Baumann P, Nil R, Souche A, Montaldi S, Baettig D, Lambert S, Uehlinger C, Kasas A, Amey M, Jonzier-Perey M (1996): A double-blind, placebo-controlled study of citalopram with and without lithium in the treatment of therapy-resistant depressive patients: A clinical, pharmacokinetic, and pharmacogenetic investigation. J Clin Psychopharmacol 16:307-314

Belmaker RH, Bersudsky Y, Agam G, Levine J, Kofman O (1996): How does lithium work on manic depression? Clinical and Psychological correlates of the inositol theory. Ann Rev Med 47:47-56

Blier P, De Montigny C. (1985): Short-term lithium administration enhances serotonergic neurotransmission: Electrophysiological evidence in the rat CNS. Eur J Pharmacol 113:69-77

Blier P, De Montigny C., Tardiff D. (1987): Short-term lithium treatment enhances responsiveness of postsynaptic 5-HT1A receptors without altering 5-HT autoreceptor sensitivity: An electrophysiological study in the rat brain. Synapse 1:225-232

Carli M, Afkhami-Dastjerdian S, Reader TA (1997): Effects of a chronic lithium treatment on cortical serotonin uptake sites and 5- $\mathrm{HT}_{1 \mathrm{~A}}$ receptors. Neurochem Res 22:427-435

Cotman CW, Matthews DA (1971): Synaptic plasma membranes from rat brain synaptosomes: Isolation and partial characterization. Biochim Biophys Acta 249: 380-394

Cowen PJ, Mac Cance SL, Ware CJ, Cohen PR, Chalmers JS, Julier DL (1991): Lithium in tricyclic-resistant depression. Correlation of increased brain 5-HT function with clinical outcome. Br J Psychiat 159:341-346

de Montigny C, Cournoyer G, Morissette R, Langlois R, Caille G (1983): Lithium carbonate addition in tricyclic antidepressant-resistant unipolar depression. Correlations with the neurobiologic actions of tricyclic antidepressant drugs and lithium ion on the serotonin system. Arch Gen Psychiat 40:1327-1334

Francès, H (1988): New animal model of social behavioral deficit: Reversal by drugs. Pharmacol Biochem Behav 31:467-470

Francès H, Lienard C, Fermanian J (1990): Improvement of the isolation-induced social behavioral deficit involves activation of the 5- $\mathrm{HT}_{1 \mathrm{~B}}$ receptors. Prog Neuropsychopharmacol Biol Psychiat 14:91-102

Friedman E, Wang HY (1988): Effect of chronic lithium treatment on 5-hydroxytryptamine autoreceptors and release of $5-\left[{ }^{3} \mathrm{H}\right]$ hydroxytryptamine from rat brain cortical, hippocampal, and hypothalamic slices. J Neurochem 50:195-201

Gershon S, Soares JC (1997): Current therapeutic profile of lithium. Arch Gen Psychiat 54:16-20

Grahame-Smith DG (1992): Serotonin in affective disorders. Int Clin Psychopharmacol 6:5-13

Green AR, Grahame-Smith DG (1976): Effects of drugs on the processes regulating the functional activity of brain 5-hydroxytryptamine. Nature 260: 487-491

Hide I, Yamawaki S (1989): Inactivation of presynaptic 5-HT autorecepteurs by lithium in rat hippocampus. Neurosci Lett 107:323-326

Hotta I, Yamawaki S, Segawa T (1986): Long-term lithium treatment causes serotonin receptor downregulation via serotonergic presynapses in rat brain. Neuropsychobiology 16:19-26

Hotta I, Yamawaki S (1988): Possible involvement of presynaptic 5-HT autoreceptors in effect of lithium on 5-HT release in hippocampus of rat. Neuropharmacology 27:987-992

Hoyer D, Clarke DE, Fozard JR, Hartig PR, Martin GR, Mylecharane EJ, Saxena PR, Humphrey PP (1994): VII. International Union of 25 Pharmacology Classification of Receptors for 5-Hydroxytryptamine (Serotonin). Pharmacol Rev 46:157-203

Hyttel J (1982): Citalopram-pharmacological profile of a specific serotonin uptake inhibitor with antidepressant activity. Prog Neuropsychopharmacol Biol Psychiat 6:277-295

Lowry OH, Rosebrough, NJ, Farr AL, Randall RJ (1951): Protein measurement with the folin phenol reagent. J Biol Chem 193:265-275 
Manji HK, Potter WZ, Lenox RH (1995): Signal transduction pathways. Molecular targets for lithium's actions. Arch Gen Psychiat 52:531-543

Nixon MK, Hascoet M, Bourin M, Colombel MC (1994): Additive effects of lithium and antidepressants in the forced swimming test: Further evidence for involvement of the serotoninergic system. Psychopharmacology 115:59-64

Odagaki Y, Koyama T, Yamashita I (1991): No alterations in the $5-\mathrm{HT}_{1 \mathrm{~A}}-$ mediated inhibition of forskolin-stimulated adenylate cyclase activity in the hippocampal membranes from rats chronically treated with lithium or antidepressants. J Neural Transm 86:85-96

Odagaki Y, Koyama Y, Yamashita I (1992): Lithium and serotonergic neural transmission: A review of pharmacological and biochemical aspects in animal studies. Lithium 3:95-107

Okamoto Y, Motohasi N, Hayakawa H, Muraoka M, Yamawaki S (1996): Addition of lithium to chronic antidepressant treatment potentiates presynaptic serotonergic function without changes in serotonergic receptors in the rat cerebral cortex. Neuropsychobiology 33: $17-20$

Owen MJ, Neal Morgan W, Plott SJ, Nemeroff CB (1997): Neurotransmitter receptor and transporter binding profile of antidepressants and their metabolites. J Pharmacol Exp Ther 283:1305-1322

Palacios JM, Mengod G, Hoyer D (1993): Brain serotonin receptor subtypes: Radioligand binding assays, second messengers, ligand autoradiography, and in situ hybridization histochemistry. Methods Neurosci 12:238-262

Pauwels PJ, Tardif S, Palmier C, Wurch T, Colpaert FC (1997): How efficacious are 5-HT1B/D receptor ligands? An answer from GTP gamma $S$ binding studies with stably transfected C6-glial cell lines. Neuropharmacology 36:499-512

Plenge P, Mellerup ET, Jorgensen OS (1992): Lithium treatment regimens induce different changes in $[3 \mathrm{H}]$ Paroxetine binding protein and other rat brain protein. Psychopharmacology 106:131-135

Price LH, Charney DS, Delgado PL, Heninger GR (1990): Lithium and serotonin function: Implications for the serotonergic hypothesis of depression. Psychopharmacology 100:3-12

Price LH, Heninger GR (1994): Drug therapy: Lithium in the treatment of mood disorders. N Engl J Med 331:591-598

Redrobe JP, Bourin M (1999): Evidence of the activity of lithium on $5-\mathrm{HT}_{1 \mathrm{~B}}$ receptors in the mouse forced swimming test: Comparison with carbamazepine and sodium valproate. Psychopharmacology 141:370-377

Salomon Y, Londos C, Rodbell MA (1974): Highly sensitive adenylate cyclase assay. Anal Biochem 58:541-548

Scatchard G (1949): The attractions of proteins for small molecules and ions. Ann NY Acad Sci 51:660-672

Schildkraut JJ (1973): The effects of lithium on norepinephrine turnover and metabolism: basic and clinical studies. In Gershon S and Shopsin B (eds), Lithium, Its Role in Psychiatric Research and Treatment. New York, Plenum, pp 51-73

Schou M, Thomsen K (1975): Lithium Prophylaxis of recurrent endogenous affective disorder. In Johnson FN (ed), Lithium Research and Therapy. New York, Academic Press, pp 3-85

Schou M (1997): Forty years of lithium treatment. Arch Gen Psychiat 54:9-15

Sharp T, Bramwell SR, Lambert P, Grahame-Smith DG (1991): Effect of short- and long-term administration of lithium on the release of endogenous 5-HT in the hippocampus of the rat in vivo and in vitro. Neuropharmacology 30:977-984

Siever LJ, Kahn RS, Lawlor BA, Trestman RL, Lawrence TL, Coccaro EF (1991): II. Critical issues in defining the role of serotonin in psychiatric disorders. Pharmacol Rev 43:509-525

Soares JC, Gershon S (1998): The lithium ion-A foundation for psychopharmacological specificity. Neuropsychopharmacology 19:167-182

Thomas DR, Faruq SA, Balcarek JM, Brown AM (1995): Pharmacological characterisation of $\left[{ }^{35} \mathrm{~S}\right]-\mathrm{GTP} \gamma \mathrm{S}$ binding to Chinese hamster ovary cell membranes stably expressing cloned human $5-\mathrm{HT}_{1 \mathrm{D}}$ receptor subtypes. J Recept Signal Transduct Res 15:199-211

Treiser SL, Cascio CS, O'Donohue TL, Thoa NB, Jacobowitz DM, Kellar KJ (1981): Lithium increases serotonin release and decreases serotonin receptors in the hippocampus. Science 213:1529-1531

Treiser S, Kellar KJ (1980): Lithium: Effects on serotonin receptors in rat brain. Eur J Pharmacol 64:183-185

Wang HY, Friedman E (1988): Chronic lithium: Desensitization of autoreceptors mediating serotonin release. Psychopharmacology 94:312-314

Wood AJ, Goodwin GM (1987): A review of the biochemical and neuropharmacological actions of lithium. Psychol Med 17:579-600 